\title{
THE PATHOGENESIS OF YERSINIA ENTEROCOLITICA INFECTION IN GNOTOBIOTIC PIGLETS
}

\author{
R. M. Robins-Browne, S. Tzipori, Gena Gonis*, Jane Hayes, Maree Withers \\ AND J. KAYA PRPIC*
}

Attwood Institute for Veterinary Research, Westmeadows, Victoria 3047 and *Department of Microbiology, University of Melbourne, Parkville, Victoria 3052, Australia

SUMmARY. Yersinia enterocolitica is an important cause of enteritis and mesenteric adenitis in many countries. However the pathogenesis of the disease caused by this organism has not been fully elucidated. Most isolates from clinical material possess two independent properties associated with virulence whose relative contribution to the development of disease is not known. These are the ability to penetrate the intestinal wall, which is thought to be controlled by a plasmid gene, and the production of heat-stable enterotoxin, which is controlled by a chromosomal gene. In this study, we infected neonatal gnotobiotic piglets with strains of $Y$. enterocolitica expressing these two properties in various combinations. The suitability of the piglet model was shown in experiments in which piglets fed virulent $Y$. enterocolitica serogroup $\mathrm{O} 3$ developed a clinical illness related to the size of the inoculum, which was accompanied by intestinal lesions similar to those reported in naturally and experimentally infected people and animals. The results confirmed the key role of a $47 \times 10^{6}$-mol. wt plasmid in the pathogenicity of $Y$. enterocolitica, but suggested that penetration of the intestinal wall may be governed by chromosomal rather than plasmid-borne genes. No role for enterotoxin in the pathogenesis of yersiniosis was shown, although there was evidence that enterotoxin may promote intra-intestinal proliferation of $Y$. enterocolitica, thus favouring increased shedding of bacteria and encouraging their spread between hosts.

\section{INTRODUCTION}

Enteropathogenic bacteria may be classified as primarily enterotoxigenic or enteroinvasive (Plotkin et al., 1979). Yersinia enterocolitica, an important cause of gastroenteritis and mesenteric adenitis in some parts of the world, is generally thought to be enteroinvasive (Carter, $1975 a$ and $b$ ). The invasive capacity of $Y$. enterocolitica is associated with possession of a $(40-48) \times 10^{6}$-mol. wt plasmid that provides the bacteria with various novel characteristics, including increased virulence for labora-

Received 23 Jul. 1984; accepted 21 Sep. 1984.

Address for correspondence: Dr R. M. Robins-Browne, Department of Microbiology, University of Melbourne, Parkville, Victoria 3052, Australia. 
tory animals, a dependence on calcium for growth, enhanced binding of haemin and Congo red, and altered surface properties that cause autoagglutination, resistance to the bactericidal effects of human serum, expression of new outer-membrane proteins and increased hydrophobicity (Portnoy et al., 1981; Martinez, 1983; Prpic et al., 1983). These properties are expressed almost exclusively during growth at $37^{\circ} \mathrm{C}$.

In addition to their enteroinvasive property, many isolates of $Y$. enterocolitica from food or clinical material also produce a heat-stable enterotoxin, whose physicochemical properties, antigenicity and mechanism of action are very similar to those of the heat-stable enterotoxin of Escherichia coli (Robins-Browne et al., 1979; Okamoto et al., 1983a). Genes for enterotoxin production are probably borne on the bacterial chromosome, and, in contrast to the plasmid-encoded characteristics, are typically expressed during growth at temperatures between 20 and $30^{\circ} \mathrm{C}$.

Although possession of a plasmid associated with virulence is unquestionably a prerequisite for expression of enteropathogenicity by $Y$. enterocolitica, the relative contribution of plasmids and enterotoxigenicity to the pathogenesis of diarrhoea caused by $Y$. enterocolitica is not known. To investigate this question, we developed a model of $Y$. enterocolitica enteritis in neonatal gnotobiotic piglets. This paper describes the model and demonstrates its value for resolving some of the questions surrounding the pathogenesis of yersiniosis.

\section{MATERIALS AND METHODS}

Bacteria. The strains of Yersinia enterocolitica used in this study and their properties are listed in table I. Strain 30.42 .67 belongs to serogroup O3, biotype 4, and was first isolated from a patient in Sweden. Two spontaneous mutants of this strain were obtained in our laboratory. These were strain $30.42 .67 \mathrm{CR}^{-}$which is enterotoxigenic but lacks the $47 \times 10^{6}-\mathrm{mol}$. wt plasmid associated with virulence, and strain $30.42 .67 \mathrm{ST}^{-}$which carries a $47 \times 10^{6}-\mathrm{mol}$. wt plasmid but is no longer enterotoxigenic. Strain AM9 belongs to serogroup O5, biotype 1, and was first isolated from cow's milk at an Australian dairy farm (Hughes, 1979).

All bacteria were cultivated on Congo red-acid morpholine-sulphonic acid pigmentation (CRAMP) agar at $25^{\circ} \mathrm{C}$ for $72 \mathrm{~h}$ (Prpic et al., 1983). Several Congo-red positive (plasmid-bearing) and negative (without the plasmid) colonies were each selected for subculture on two nutrient-agar plates, which were incubated at 25 and $37^{\circ} \mathrm{C}$ respectively. Approximately equal numbers of bacteria cultivated at 25 and $37^{\circ} \mathrm{C}$ were harvested in sterile physiological saline, washed once and adjusted to a desired opacity. For each inoculum, viable counts were determined, and the proportion of plasmid-bearing bacteria was evaluated by plating on CRAMP agar.

Virulence characters. Tests for the following characteristics which have been associated with virulence were performed (Portnoy et al., 1981; Prpic et al., 1983): binding of Congo red, calcium dependence at $37^{\circ} \mathrm{C}$, autoagglutination and possession of a plasmid. The susceptibility of

TABLE I

Strains of Y. enterocolitica used

\begin{tabular}{|c|c|c|c|c|c|c|c|c|}
\hline Strain no. & Serogroup & Origin & $\begin{array}{l}\text { Congo } \\
\text { red } \\
\text { reaction }\end{array}$ & $\begin{array}{c}\text { Calcium } \\
\text { dependence }\end{array}$ & $\begin{array}{l}\text { Auto- } \\
\text { agglutination }\end{array}$ & $\begin{array}{c}\text { Entero- } \\
\text { toxin }\end{array}$ & $\begin{array}{c}\text { Kerato- } \\
\text { conjunctivitis } \\
\text { test }\end{array}$ & $\underset{\text { size }}{\text { Plasmid }}$ \\
\hline 30.42 .67 & $\mathrm{O} 3$ & man & + & + & + & + & - & $47 \times 10^{6}$ \\
\hline $30.42 .67 \mathrm{CR}^{-}$ & $\mathrm{O} 3$ & mutant & - & - & - & + & - & none \\
\hline $30.42 .67 \mathrm{ST}^{-}$ & $\mathrm{O} 3$ & mutant & + & + & + & - & - & $47 \times 10^{6}$ \\
\hline AM9 & O5 & milk & + & - & - & + & - & $40 \times 10^{6}$ \\
\hline
\end{tabular}


bacteria to the bactericidal effect of human, pig or rabbit serum was determined at $37^{\circ} \mathrm{C}$ (Prpic et al., 1983). For assessment of enterotoxigenicity, bacteria were grown at $25^{\circ} \mathrm{C}$ for $48 \mathrm{~h}$ in Casamino acid-yeast extract broth (Evans et al., 1973), supplemented with sucrose $0 \cdot 25 \% \mathrm{w} / \mathrm{v}$. Culture filtrates were examined for enterotoxin in the modified suckling-mouse assay (Robins-Browne et al., 1979). Suckling mice were also used to assay the intestinal contents of diarrhoeic animals for enterotoxic activity. Enteroinvasive capacity was assessed in the guinea pig keratoconjunctivitis test (Sereny, 1955).

Experimental animals. Twelve piglets were delivered by Caesarian section and maintained in pairs in gnotobiotic conditions as described by Makin and Tzipori (1980). Within 2 days of birth, they were given $3 \mathrm{ml}$ of a suspension of the test organism by mouth (table II). One piglet (P7) was delivered by Caesarian section and maintained free of specific pathogens for 13 days before infection with $Y$. enterocolitica.

Six rabbits aged 8 weeks, with a mean body weight of $1.2 \mathrm{~kg}$, were kept in pairs in isolators. Four were given oral inocula of $5 \times 10^{9} \mathrm{cfu}$ of strain 30.42 .67 in $1.5 \mathrm{ml}$ of $10 \% \mathrm{NaHCO}_{3}$. Control rabbits received the same amount of sterile $10 \% \mathrm{NaHCO}_{3}$.

Piglets and rabbits were observed twice daily for clinical illness. Rectal swabs were cultured on MacConkey Agar and Yersinia Selective (CIN) Agar (Oxoid).

Necropsy procedure. Piglets were examined at necropsy 1-6 days after inoculation (table II). Samples were taken from five equally spaced sites in the small intestine, as well as from the stomach, caecum, colon, liver, spleen and mesenteric lymph nodes. After fixation in neutral buffered formalin, samples were sectioned and stained with haematoxylin and eosin, and by the peroxidase-antiperoxidase (PAP) technique (Taylor, 1978), with hyperimmune rabbit antisera.

Samples for electronmicroscopy were fixed in chilled glutaraldehyde $2.5 \%$ in $0.1 \mathrm{M}$ sodium

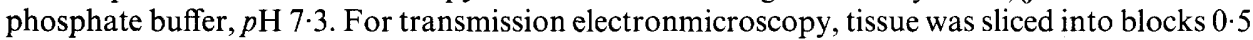
$\mathrm{mm}$ thick, post-fixed in aqueous osmium tetroxide $2 \%$, en bloc stained with uranyl acetate $2 \%$ in $70 \%$ acetone, dehydrated in acetone and embedded in Araldite-Epon. Sections $0.5 \mu \mathrm{m}$ thick were stained with methylene blue and examined by light microscopy to select lesions for thin sectioning. Ultrathin sections were stained with lead citrate.

Tissue for scanning electronmicroscopy was post-fixed overnight in aqueous osmium textroxide $1 \%$, washed thoroughly in distilled water and treated with thiocarbohydrazide by the OTOTO method (Kelley et al., 1973) before dehydration and critical point drying. Specimens were mounted on stubs with silver paint and examined at $20 \mathrm{kV}$ without metal coating.

Samples for quantitative bacterial culture were taken from the proximal, mid and distal small intestine, as well as from the spleen, liver, mesenteric lymph nodes and heart blood. For these investigations, tissue was homogenised in nine volumes of physiological saline, from which ten-fold dilutions were prepared and the numbers of yersiniae counted on nutrient agar and CIN agar. Heart blood was cultured on 5\% sheep-blood agar directly and after enrichment for $48 \mathrm{~h}$ in brain heart infusion broth. All media were incubated aerobically at $25^{\circ} \mathrm{C}$.

\section{RESULTS}

\section{Clinical findings}

The outcome of giving piglets and rabbits the four strains of $Y$. enterocolitica is summarised in table II. The clinical response to infection in piglets given the virulent strain 30.42.67 was related to the size of inoculum, and ranged from a subclinical or mild illness in animals given $2 \times 10^{9} \mathrm{cfu}$ to death in those given $4 \times 10^{10} \mathrm{cfu}$. After an incubation period of 2 days, affected piglets developed anorexia, often accompanied by diarrhoea, characterised by intermittent passage of watery, bile-stained faeces containing mucus and clotted milk. Most animals were hunched and depressed and had ruffled coats. They were not dehydrated. Two piglets, P5 and P6, died within $18 \mathrm{~h}$ of infection, but showed no signs of illness.

The ability to produce enterotoxin was not related to pathogenicity because the 
TABLE II.

Experimental design and outcome of infection

\begin{tabular}{|c|c|c|c|c|c|c|c|}
\hline $\begin{array}{l}\text { Experiment } \\
\text { no. }\end{array}$ & $\begin{array}{l}\text { Animal } \\
\text { species } \\
\text { and no. }\end{array}$ & $\begin{array}{c}\text { Age } \\
\text { (days) }\end{array}$ & $\begin{array}{c}Y . \text { enterocolitica } \\
\text { strain }\end{array}$ & $\begin{array}{l}\text { Inoculum } \\
\text { size (cfu) }\end{array}$ & $\begin{array}{l}\text { Interval } \\
\text { before necropsy } \\
\text { (days) }\end{array}$ & $\begin{array}{c}\text { Clinical } \\
\text { signs }\end{array}$ & $\begin{array}{l}\text { Post-mortem } \\
\text { findings }\end{array}$ \\
\hline 1 & $\begin{array}{l}\mathrm{P} 1 \\
\mathrm{P} 2\end{array}$ & $\begin{array}{l}2 \\
2\end{array}$ & $\begin{array}{l}30.42 .67 \\
30.42 .67\end{array}$ & $\begin{array}{l}2 \times 10^{9} \\
2 \times 10^{9}\end{array}$ & $\begin{array}{l}4 \\
6\end{array}$ & $\begin{array}{c}\text { anorexia } \\
\text { none }\end{array}$ & $\begin{array}{l}\text { enterocolitis } \\
\text { enterocolitis }\end{array}$ \\
\hline 2 & $\begin{array}{l}\text { P3 } \\
\text { P4 }\end{array}$ & $\begin{array}{l}1 \\
1\end{array}$ & $\begin{array}{l}30.42 .67 \\
30.42 .67\end{array}$ & $\begin{array}{l}10^{10} \\
10^{10}\end{array}$ & $\begin{array}{l}2 \\
3\end{array}$ & $\begin{array}{c}\text { none } \\
\text { diarrhoea }\end{array}$ & $\begin{array}{c}\text { enteritis } \\
\text { enterocolitis }\end{array}$ \\
\hline 3 & $\begin{array}{l}\text { P5 } \\
\text { P6 }\end{array}$ & $\begin{array}{l}1 \\
1\end{array}$ & $\begin{array}{l}30.42 .67 \\
30.42 .67\end{array}$ & $\begin{array}{l}4 \times 10^{10} \\
4 \times 10^{10}\end{array}$ & 1 & $\begin{array}{l}\text { died } \\
\text { died }\end{array}$ & $\begin{array}{l}\text { N.D. } \\
\text { N.D. }\end{array}$ \\
\hline 4 & P7 & 13 & 30.42 .67 & $4 \times 10^{9}$ & 6 & none & normal \\
\hline 5 & $\begin{array}{l}\text { P8 } \\
\text { P9 }\end{array}$ & 1 & $\begin{array}{l}30.42 .67 \mathrm{ST}^{-} \\
30.42 .67 \mathrm{ST}^{-}\end{array}$ & $\begin{array}{l}10^{10} \\
10^{10}\end{array}$ & $\begin{array}{l}3 \\
4\end{array}$ & $\begin{array}{l}\text { diarrhoea } \\
\text { diarrhoea }\end{array}$ & $\begin{array}{c}\text { enterocolitis } \\
\text { enteritis }\end{array}$ \\
\hline 6 & $\begin{array}{l}\text { P10 } \\
\text { P11 }\end{array}$ & 1 & $\begin{array}{l}30.42 .67 \mathrm{CR}^{-} \\
30.42 .67 \mathrm{CR}^{-}\end{array}$ & $\begin{array}{l}4 \times 10^{10} \\
4 \times 10^{10}\end{array}$ & $\begin{array}{l}2 \\
3\end{array}$ & $\begin{array}{l}\text { none } \\
\text { none }\end{array}$ & $\begin{array}{l}\text { normal } \\
\text { normal }\end{array}$ \\
\hline 7 & $\begin{array}{l}\text { P12 } \\
\text { P13 }\end{array}$ & 1 & $\begin{array}{l}\text { AM9 } \\
\text { AM } 9\end{array}$ & $\begin{array}{l}2 \times 10^{10} \\
2 \times 10^{10}\end{array}$ & $\begin{array}{l}3 \\
4\end{array}$ & $\begin{array}{l}\text { none } \\
\text { none }\end{array}$ & $\begin{array}{l}\text { normal } \\
\text { normal }\end{array}$ \\
\hline 8 & $\begin{array}{l}\mathrm{R} 1 \text { and } 2 \\
\mathrm{R} 3 \text { and } 4 \\
\mathrm{R} 5 \text { and } 6\end{array}$ & $\begin{array}{l}56 \\
56 \\
56\end{array}$ & $\begin{array}{c}30.42 .67 \\
30.42 .67 \\
\text { none }\end{array}$ & $\begin{array}{c}5 \times 10^{9} \\
5 \times 10^{9} \\
0\end{array}$ & $\begin{array}{c}7 \\
11 \\
7,11\end{array}$ & $\begin{array}{l}\text { none } \\
\text { none } \\
\text { none }\end{array}$ & $\begin{array}{l}\text { mild enteritis } \\
\text { mild enteritis } \\
\text { normal }\end{array}$ \\
\hline
\end{tabular}

$\mathrm{P}=$ piglets; $\mathrm{R}=$ rabbits; $\mathrm{N} . \mathrm{D} .=$ not done .

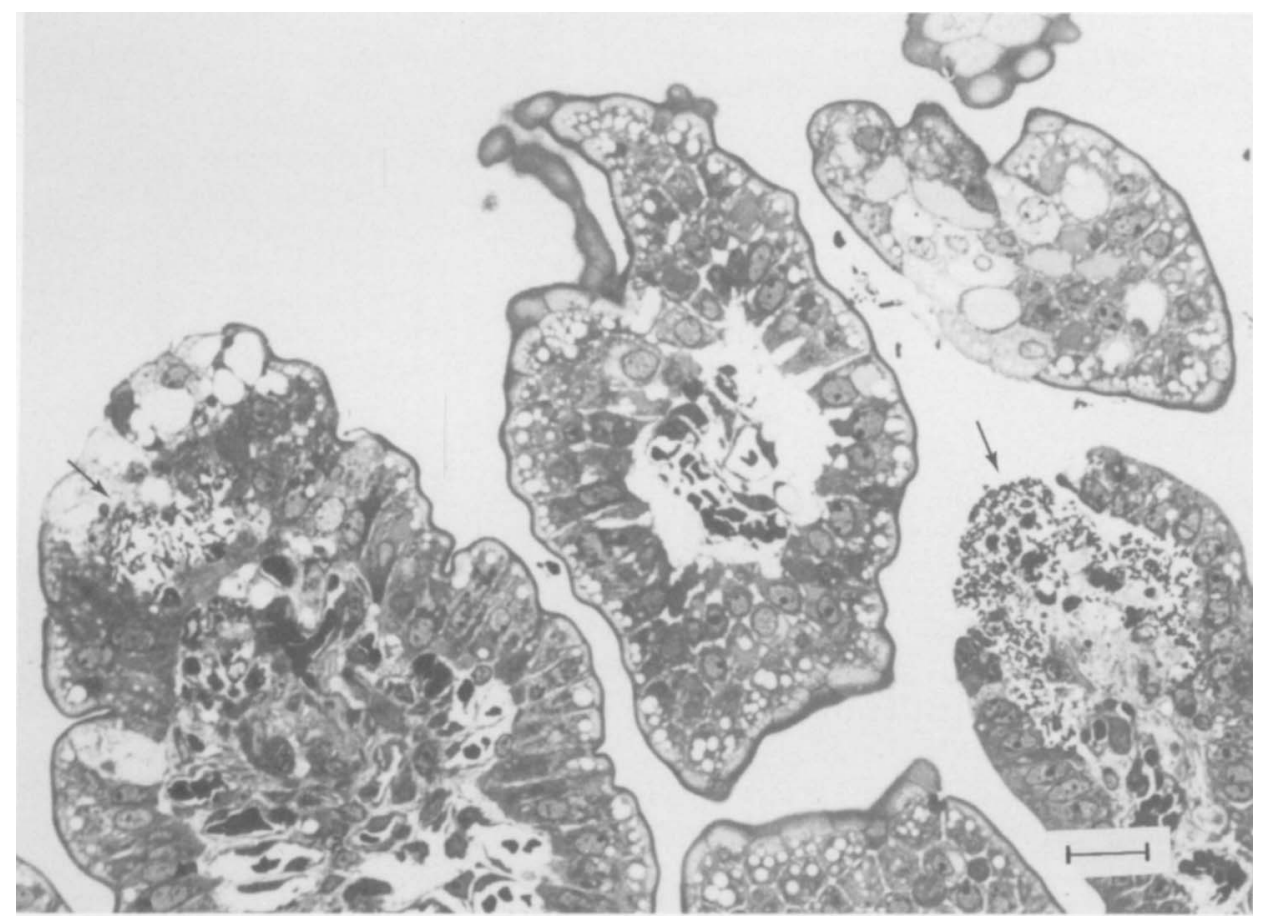

FIG. 1.--Light micrograph of a section through the mid ileum of a gnotobiotic piglet (P4, table II) $72 \mathrm{~h}$ after inoculation with $Y$. enterocolitica strain $30.42 .6710^{10} \mathrm{cfu}$. Arrows indicate bacterial microcolonies and accompanying degeneration of epithelial cells. Epoxy section. Methylene blue. Bar $=20 \mu \mathrm{m}$. 
illness produced by strain $30.42 .67 \mathrm{ST}^{-}$in piglets $\mathrm{P} 8$ and $\mathrm{P} 9$ was indistinguishable from that in piglets $\mathrm{P} 3$ and $\mathrm{P} 4$ which received a similar inoculum of the parent strain. On the other hand, strains $30.42 .67 \mathrm{CR}^{-}$and $\mathrm{AM} 9$, which lacked the $47 \times 10^{6}-\mathrm{mol}$. wt plasmid, produced no overt illness.

All four rabbits given strain 30.42 .67 remained healthy during the observation period.

\section{Pathology}

The prominent post-mortem findings are summarised in table II. In general, piglets with diarrhoea had varying amounts of yellow-green mucoid fluid in the distal small and large intestine. Mesenteric lymph nodes were moderately enlarged compared with unaffected piglets. Other visceral organs appeared normal.

All gnotobiotic piglets given strain 30.42.67 and strain 30.42.67 $\mathrm{ST}^{-}$showed similar microscopic intestinal lesions irrespective of clinical outcome. In contrast, the SPF piglet (P7) and the piglets given strains $30.42 .67 \mathrm{CR}^{-}$or AM9 displayed no histopathological changes.

The most striking feature in the intestinal tract of piglets given strain 30.42 .67 was the presence of discrete, necrotic foci in the lamina propria within ileal villi. These lesions comprised micro-colonies of coccobacilli, surrounded by varying numbers of polymorphonuclear and mononuclear inflammatory cells (figs 1 and 2). The bacteria

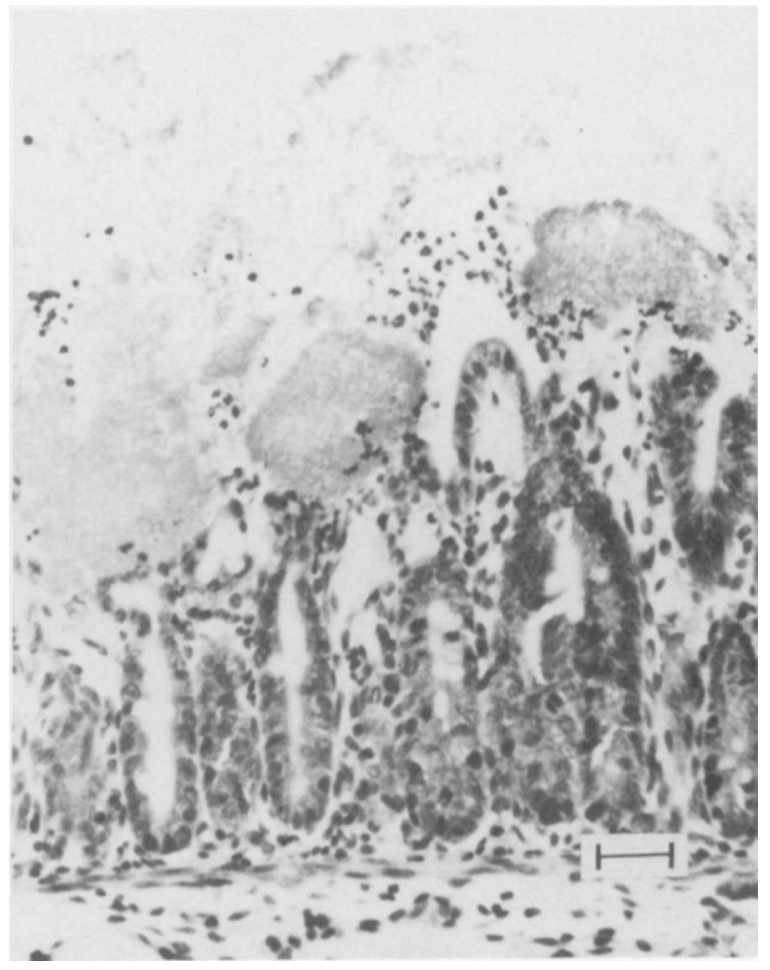

FIG. 2.- Light micrograph of a section from the mid ileum of a gnotobiotic piglet, P4, showing disruption of villous architecture and loss of epithelial lining, $72 \mathrm{~h}$ after inoculation with $Y$. enterocolitica. Inflammatory cells and accumulations of bacteria can be seen discharging into the lumen. Paraffin section. Haematoxylin and eosin. Bar $=50 \mu \mathrm{m}$. 

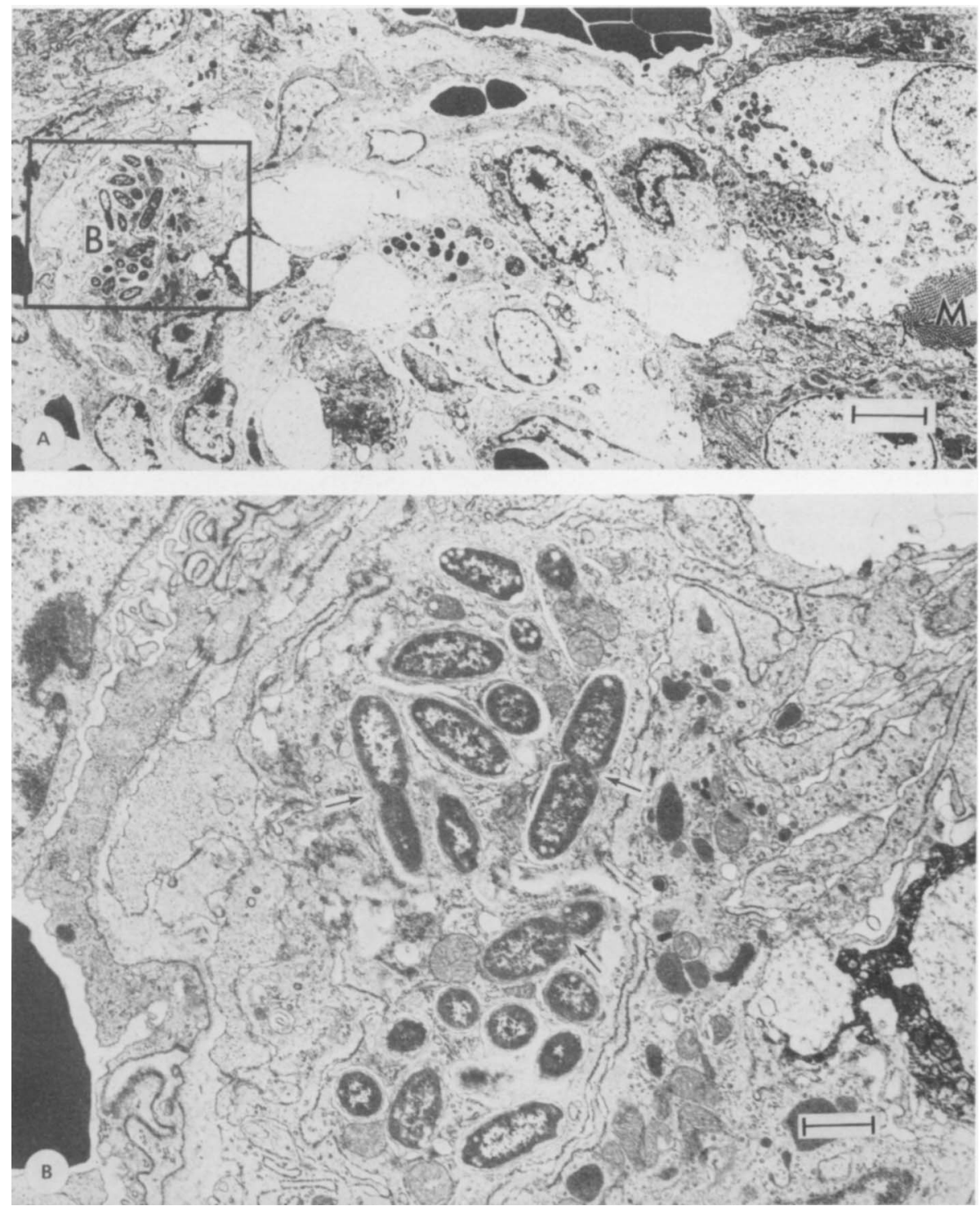

FIG. 3.-(A) Electronmicrograph of a section through the upper third of a villus in the mid ileum of a gnotobiotic piglet, $\mathrm{P} 4$, infected with $Y$. enterocolitica. Note the microvillous brush border (M) in an epithelial fold and the intracellular bacteria (B). Bar $=5 \mu \mathrm{m}$. (B) Higher power views of area B in fig. 3A showing bacteria within vacuoles of what appears to be a macrophage. Arrows indicate dividing bacteria. $\mathrm{Bar}=1 \mu \mathrm{m}$.

were identified as $Y$. enterocolitica serogroup $\mathrm{O} 3$ by staining with PAP. Electronmicroscopic examination revealed that some phagocytic cells contained actively multiplying intracytoplasmic bacteria (fig. 3).

Early lesions were well circumscribed and entirely contained within intact villi (fig. 1). In more advanced lesions, the lining epithelium was ulcerated at the villous tips (figs. 1, 2, 4 and 5). In severe cases, the entire villous architecture was lost, together with 


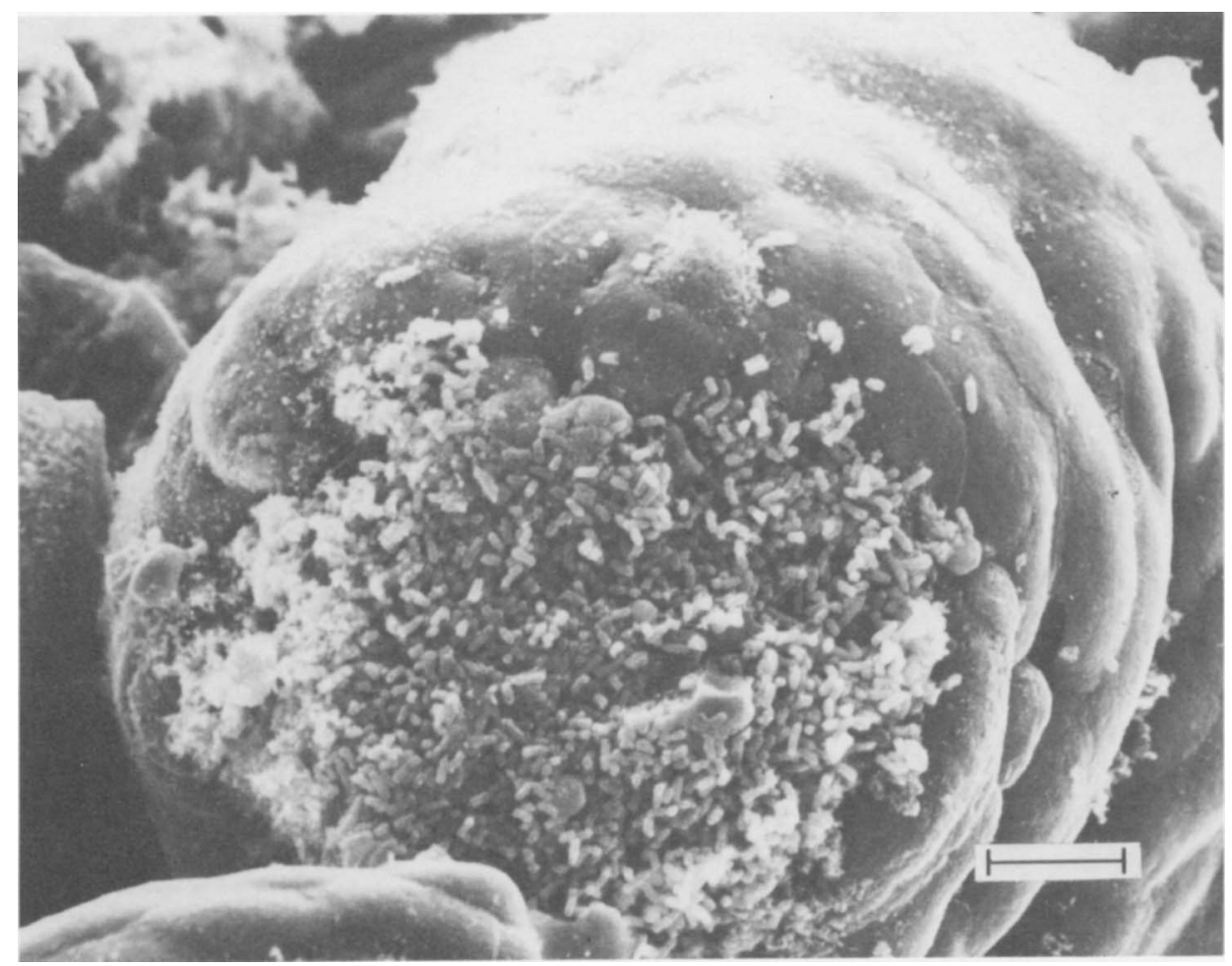

Fig. 4-Scanning electronmicrograph of the mid ileum of a gnotobiotic piglet, P4, infected with $Y$. enterocolitica. Note the bacterial colony protruding through a villous tip, which has lost its epithelial cap. $\mathrm{Bar}=10 \mu \mathrm{m}$.

the lining epithelium, and only clumps of bacteria interspersed with inflammatory cells were observed in association with apparently intact crypts (figs. 4 and 5). In the small intestine, lesions increased progressively from the proximal jejunum, where only one or two were found, to the mid and terminal ileum where almost every villus was affected.

The large intestine was less uniformly affected than the ileum, although clusters of discrete lesions similar to those in the small intestine were seen in several areas. Lesions were often associated with a disrupted epithelial lining, through which bacteria and inflammatory cells spilled into the intestinal lumen (fig. 5).

In contrast to the findings in piglets, only a few lesions were seen in the intestines of infected rabbits. Two rabbits killed 7 days after inoculation demonstrated characteristic micro-colonies in the lamina propria and glands of the terminal ileum. Animals killed on the eleventh day showed, additionally, granulomatous lesions in mesenteric lymph nodes, containing mononuclear cells and areas of necrosis. PAP-staining indicated that bacteria within the intestinal wall and lymphoid follicles were $Y$. enterocolitica serogroup $\mathrm{O} 3$.

Visceral organs from infected piglets and rabbits appeared normal and showed no evidence of bacterial invasion, although high bacterial counts were obtained from some of these organs (see below). 


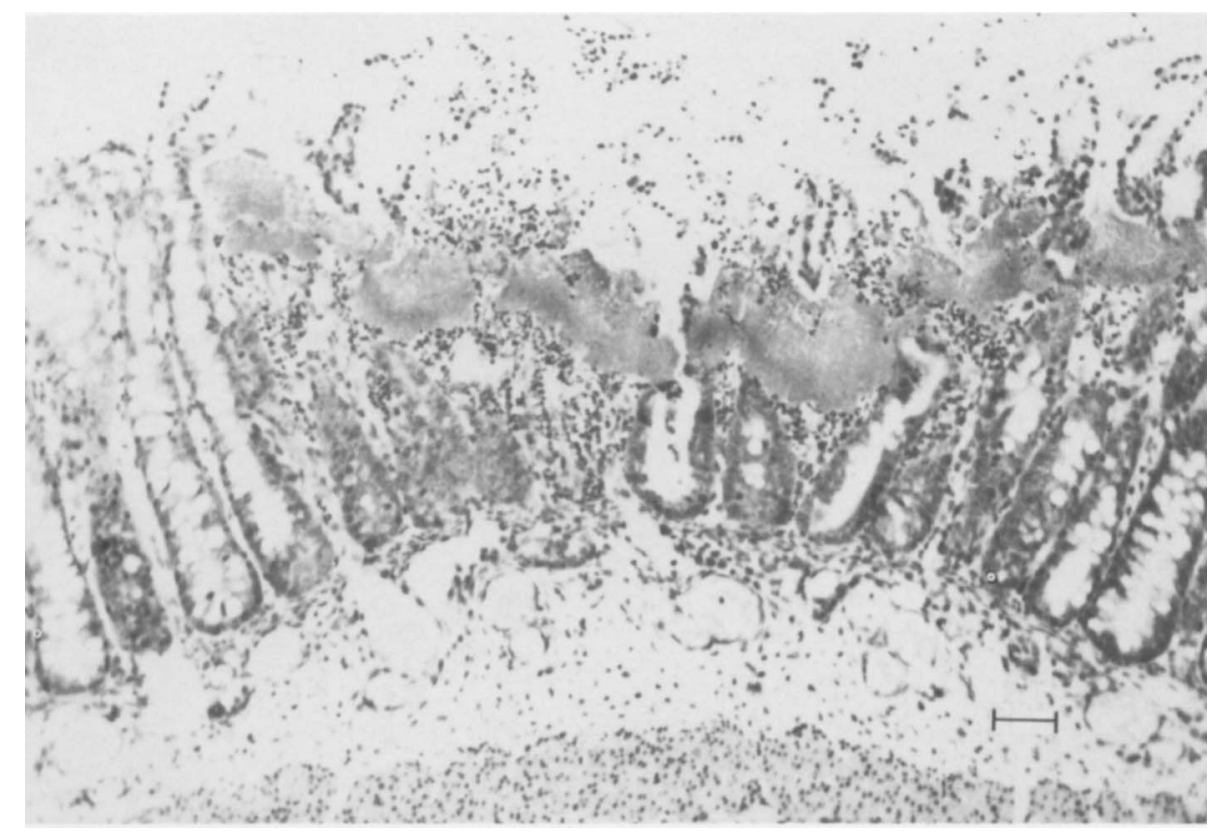

FIG. 5. Light micrograph of the spiral colon of a gnotobiotic piglet, $\mathrm{P} 4,72 \mathrm{~h}$ after receiving $Y$. enterocolitica, showing bacterial microcolonies, submucosal oedema and loss of epithelial lining. Note displacement and possible occlusion of some glands. Paraffin section. Haematoxylin and eosin. Bar $=100 \mu \mathrm{m}$.

\section{Bacterial colonisation}

The results of the quantitative bacteriological studies are given in table III. Plasmid-bearing strains 30.42 .67 and $30.42 .67 \mathrm{ST}^{-}$successfully colonised the intestine of all seven piglets and three of four rabbits. Although the numbers of bacteria recovered from different animals showed wide variations, more bacteria were consistently obtained from the distal than from the proximal small intestine. The extent of bacterial colonisation did not correlate with the severity of clinical or pathological findings; even animals with no clinical or pathological abnormalities yielded large numbers of bacteria.

Strains $30.42 .67 \mathrm{ST}^{-}$and $30.42 .67 \mathrm{CR}^{-}$appeared to colonise the gut less efficiently than the parent strain, although the number of piglets given these mutants was too small to permit statistical evaluation of the findings.

Counts of strain 30.42 .67 in visceral organs ranged from $10^{4}$ to $10^{9} \mathrm{cfu} / \mathrm{g}$, the highest being in mesenteric lymph nodes. Strains 30.42 .67 and $30.42 .67 \mathrm{ST}^{-}$were consistently obtained from heart blood, although in numbers too low $(<10 / \mathrm{ml})$ to be detected by direct plating. Strain $30.42 .67 \mathrm{CR}^{-}$was also isolated from the blood and internal organs of infected piglets. Plating of these isolates on CRAMP agar and direct plasmid analysis confirmed that these bacteria did not contain a plasmid and were not revertanis to the parent strain.

In contrast to the above results, strain AM9 was obtained in comparatively low numbers from the distal small intestine of only one of two piglets and not at all from the blood or internal organs of either animal. 
TABLE III.

Quantitative recovery of bacteria from intestinal mucosa and internal organs of gnotobiotic piglets fed four Y. enterocolitica strains

\begin{tabular}{|c|c|c|c|c|}
\hline \multirow[b]{2}{*}{ Tissue sampled } & \multicolumn{4}{|c|}{$\begin{array}{c}\text { Mean number of bacteria }\left(\log _{10} \mathrm{cfu} / \mathrm{g}\right) \text { recovered of } \\
\text { strain }\end{array}$} \\
\hline & $\begin{array}{l}30.42 .67 \\
(\mathrm{n}=7)^{*}\end{array}$ & $\begin{array}{l}30.42 .67 \mathrm{ST}^{-} \\
(\mathrm{n}=2)\end{array}$ & $\begin{array}{l}\text { 30.42.67 } \mathrm{CR}^{-} \\
\quad(\mathrm{n}=2)\end{array}$ & $\begin{array}{c}\text { AM9 } \\
(\mathrm{n}=2)\end{array}$ \\
\hline $\begin{array}{l}\text { Small intestine: } \\
\text { proximal } \\
\text { mid } \\
\text { distal } \\
\text { Liver } \\
\text { Spleen } \\
\text { Mesenteric lymph } \\
\text { node }\end{array}$ & $\begin{array}{l}8.2(7 \cdot 4-9.0) \dagger \\
9 \cdot 2(7 \cdot 6-10 \cdot 7) \\
9 \cdot 6(8 \cdot 5-10 \cdot 7) \\
6.4(5 \cdot 0-7 \cdot 7) \\
6 \cdot 1(4 \cdot 9-8 \cdot 8) \\
7.6(6 \cdot 7-9 \cdot 0)\end{array}$ & $\begin{array}{l}6 \cdot 4 \\
6 \cdot 9 \\
8 \cdot 0 \\
\text { N.D. } \\
\text { N.D. } \\
\text { N.D. }\end{array}$ & $\begin{array}{l}6 \cdot 3 \\
6 \cdot 8 \\
6 \cdot 8 \\
5 \cdot 5 \\
5 \cdot 2 \\
6 \cdot 0\end{array}$ & $\begin{array}{l}<5 \\
<5 \\
6 \cdot 2 \\
<2 \\
<2 \\
<2 \\
02\end{array}$ \\
\hline Blood & $<1+$ & $<1 \ddagger$ & $<1 \ddagger$ & 0 \\
\hline
\end{tabular}

Three of four rabbits given strain 30.42 .67 shed it in the faeces, from $1-5$ days after infection up to the time of necropsy. The pattern of intestinal colonisation with this bacterium followed that in piglets, bacterial numbers increased progressively from the proximal (mean $5 \times 10^{2} \mathrm{cfu} / \mathrm{g}$ of intestinal mucosa) to the mid $\left(4 \times 10^{5} \mathrm{cfu} / \mathrm{g}\right)$ and distal $\left(2 \times 10^{6} \mathrm{cfu} / \mathrm{g}\right)$ small intestine. Mesenteric lymph nodes obtained from two rabbits given strain 30.42.67 7 days earlier were sterile, whereas those from both animals killed 11 days after infection yielded large numbers of the test organism. Bacteria were not found in the other organs examined or in heart blood.

\section{Enterotoxin assays}

Enterotoxic activity was not detected in the intestinal secretions of diarrhoeic piglets. Several colonies of strain $30.42 .67 \mathrm{ST}^{-}$obtained from the intestine and organs of infected piglets were examined for enterotoxin production; all were negative.

\section{Serum susceptibility}

Plasmid-bearing strains 30.42 .67 and $30.42 .67 \mathrm{ST}^{-}$were resistant to the bactericidal effects of human serum, whereas strains $30.42 .67 \mathrm{CR}^{-}$and AM9, which lack the $47 \times 10^{6}$-mol. wt plasmid, were susceptible. All strains, regardless of their plasmid profile, were resistant to rabbit and pig serum.

\section{DisCUSSION}

Although $Y$. enterocolitica can infect a wide variety of animal species, host range is closely correlated with serogroup (Winblad, 1973). Amongst all animals examined, only pigs consistently yield strains of serogroup $\mathrm{O} 3$ biotype 4 , which is the serobiotype most frequently associated with infections in man (Toma and Deidrick, 1975). It is not 
surprising, therefore, that piglets were susceptible to infection with strain 30.42 .67 , a clinical isolate from man.

In this study, the suitability of piglets as a model of yersiniosis was demonstrated by the close similarity between the clinical and pathological findings in experimentally infected piglets and those previously documented in naturally infected people (Bradford et al., 1974; Vantrappen et al., 1982) and sheep (McSporran et al., 1984), and in experimentally infected mice (Carter, 1975 $a$ and $b$ ) and rabbits (Une, 1977; Pai et al., 1980). In contrast to other experimental animals, however, histopathological changes in infected piglets, in particular the diffuse ileitis accompanied by mucosal ulceration with sparing of crypts, resembled the findings in man most closely (Vantrappen et al., 1982).

The greater susceptibility of neonatal gnotobiotic piglets to yersiniosis compared with other animals is probably attributable in part to their age and the virtual absence of a normal intestinal flora. In this study, a specific pathogen-free pig (P7) aged 13 days remained well for 6 days after ingesting more than $10^{9}$ virulent bacteria. The finding that this pig was not affected by this large bacterial inoculum, despite extensive intestinal colonisation, emphasizes the role of pigs as a potential reservoir of human yersiniae.

This study has confirmed the importance of plasmid-encoded properties in the pathogenesis of yersiniosis. Piglets given as many as $4 \times 10^{10} \mathrm{cfu}$ of the mutant strain 30.42.67 $\mathrm{CR}^{-}$, without the $47 \times 10^{6}$-mol. wt plasmid, remained healthy, whereas those given a similar inoculum of the parent strain died of generalised infection within $24 \mathrm{~h}$. Despite its apparent lack of virulence, strain 30.42.67 $\mathrm{CR}^{-}$did colonise the intestine and penetrate tissues to an extent where it was recovered in appreciable numbers from the blood, liver, spleen and mesenteric lymph nodes. Our findings suggest that chromosomally-encoded characteristics determine the ability of $Y$. enterocolitica to colonise and to invade tissues and that the $47 \times 10^{6}-\mathrm{mol}$. wt plasmid plays a supporting role in infection, possibly by facilitating bacterial multiplication in tissues. These observations concur with those of other workers, who have shown that the ability of $Y$. enterocolitica to invade cultured epithelial cells is associated with serobiotype and not with the presence of plasmids (Portnoy et al., 1981; Vesikari et al., 1981; Schiemann and Devenish, 1982; Okamoto et al., 1983b). In contrast to serogroup O3 strains, strain AM9, which belongs to a serogroup not normally pathogenic for humans, barely colonised the intestine of gnotobiotic piglets, and showed no propensity to invade tissues.

The survival and persistance of strain $30.42 .67 \mathrm{CR}^{-}$in piglet viscera may have been linked to its resistance to porcine serum. The pronounced susceptibility of such strains to human serum suggests that they would be unlikely to cause systemic infections in humans.

One of the enigmatic aspects of $Y$. enterocolitica enteritis is the role of enterotoxin in disease. This toxin resembles the heat-stable enterotoxin of $E$. coli in several ways (Robins-Browne et al., 1979), and might be expected to contribute to the pathogenesis of diarrhoea caused by $Y$. enterocolitica. In gnotobiotic piglets, however, the illness produced by the non-enterotoxigenic mutant strain $30.42 .67 \mathrm{ST}^{-}$was indistinguishable from that caused by the parent strain. Moreover, in keeping with the findings of Pai et al. (1980) in rabbits, we found no evidence of enterotoxin production in piglets with diarrhoea. This finding confirms Schiemann's (1981) observation that enterotoxin 
is not an essential prerequisite for the expression of virulence by $Y$. enterocolitica. It is noteworthy, however, that the numbers of strain $30.42 .67 \mathrm{ST}^{-}$recovered from the small intestine of piglets were appreciably less than in those given the toxigenic parent strain. This suggests that while enterotoxin is not essential for causing disease, it may promote intra-intestinal multiplication of yersiniae, thus increasing their shedding in faeces and aiding their transmission between hosts. This hypothesis implies a selective advantage for enterotoxin-producing bacteria, and, if confirmed, would account for the fact that the majority of $Y$. enterocolitica isolates from clinical specimens are enterotoxigenic (Pai et al., 1978; Robins-Browne et al., 1979).

In summary, this study has demonstrated that newborn gnotobiotic piglets are highly susceptible to infection with virulent $Y$. enterocolitica isolated from man. This animal model provides a means to investigate the pathogenesis of yersiniosis, and should prove useful in future investigations of the immunity to and prevention of $Y$. enterocolitica infections. The study has also illustrated the value of laboratory tests for demonstrating the virulence of $Y$. enterocolitica. Of the tests employed, calcium dependence, autoagglutination and resistance to human serum at $37^{\circ} \mathrm{C}$, all corresponded with virulence for piglets. In contrast, binding of Congo red, production of enterotoxin and the ability to cause kerato-conjunctivitis in guinea pigs correlated poorly with pathogenicity.

We are indebted to the staff of the Enteritis Section, Attwood Institute for Veterinary Research for technical assistance and to Marianne Gierveld for help in preparing the manuscript. This research was funded in part by grants from the Australian National Health and Medical Research Council and the Australian Pig Industry Research Committee. J.K.P. is the recipient of an Australian Public Service Postgraduate Study Award.

\section{REFERENCES}

Bradford W D, Noce P S, Gutman L T 1974 Pathologic features of enteric infection with Yersinia enterocolitica. Archives of Pathology 98: 17-22.

Carter PB. 1975a Pathogenicity of Yersinia enterocolitica for mice. Infection and Immunity 11: 164-170.

Carter PB 1975b Animal model: Oral Yersinia enterocolitica infection of mice. American Journal of Pathology 81: 703-706.

Evans D G, Evans D J, Gorbach S L 1973 Identification of enterotoxigenic Escherichia coli and serum antitoxin activity by the vascular permeability factor assay. Infection and Immunity 8: 731-735.

Hughes D 1979 Isolation of Yersinia enterocolitica from milk and a dairy farm in Australia. Journal of Applied Bacteriology 46: 125-130.

Kelley R O, Dekker R A F, Bluemink J G 1973 Ligand-mediated osmium binding: its application in coating biological specimens for scanning electron microscopy. Journal of Ultrastructure Research 45: 254-258.

Makin T J, Tzipori S 1980 Inexpensive techniquès for the production and maintenance of gnotobiotic piglets, calves and lambs. Australian Veterinary Journal 56: 353-358.

Martinez R J 1983 Plasmid-mediated and temperature-regulated surface properties of Yersinia enterocolitica. Infection and Immunity 41: 921-930.

McSporran K D, Hansen L M, Saunders B W, Damsteegt A 1984 An outbreak of diarrhoea in hoggets associated with infection by Yersinia enterocolitica. New Zealand Veterinary Journal 32: 38-39.

Okamoto K, Miyama A, Takeda T, Takeda Y, Miwatani T, 1983a Cross-neutralization of heat-stable enterotoxin activity of enterotoxigenic Escherichia coli and of Yersinia enterocolitica. FEMS Microbiology Letters 16: 85-87. 
Okamoto K, Inoue T, Moriyama T, Shimizu K, Miyama A $1983 b$ Virulence and cytotoxicity of Yersinia enterocolitica. Japanese Journal of Medical Science and Biology 36: 131-132.

Pai C H, Mors V, Seemayer T A 1980 Experimental Yersinia enterocolitica enteritis in rabbits. Infection and Immunity 28: 238-244.

Pai C H, Mors V, Toma S 1978 Prevalence of enterotoxigenicity in human and nonhuman isolates of Yersinia enterocolitica. Infection and Immunity 22: 334-338.

Plotkin G R, Kluge R M, Waldman R H 1979 Gastroenteritis: etiology, pathophysiology and clinical manifestations. Medicine (Baltimore) 58: 95-114.

Portnoy D A, Moseley S L, Falkow S 1981 Characterization of plasmids and plasmid-associated determinants of Yersinia enterocolitica pathogenesis. Infection and Immunity 31: 775-782.

Prpic J K, Robins-Browne R M, Davey R B 1983 Differentiation between virulent and avirulent Yersinia enterocolitica isolates by using Congo red agar. Journal of Clinical Microbiology 18: $486-490$.

Robins-Browne R M, Still C S, Miliotis M D, Koornhof H J 1979 Mechanism of action of Yersinia enterocolitica enterotoxin. Infection and Immunity 25: 680-684.

Schiemann D A 1981 An enterotoxin-negative strain of Yersinia enterocolitica serotype 0:3 is capable of producing diarrhea in mice. Infection and Immunity 32: 571-574.

Schiemann D A, Devenish J A 1982 Relationship of HeLa cell infectivity to biochemical, serological, and virulence characteristics of Yersinia enterocolitica. Infection and Immunity 35: 497-506.

Sereny B 1955 Experimental Shigella keratoconjunctivitis: a preliminary report. Acta Microbiologica Academiae Scientiarum Hungaricae 2: 293-296.

Taylor C R 1978 Immunoperoxidase techniques: practical and theoretical aspects. Archives of Pathology and Laboratory Medicine 102: 113-121.

Toma S, Deidrick V R 1975 Isolation of Yersinia enterocolitica from swine. Journal of Clinical Microbiology 2: 478-481.

Une T 1977 Studies on the pathogenicity of Yersinia enterocolitica. I. Experimental infection in rabbits. Microbiology and Immunology 21: 349-363.

Vantrappen G, Geboes K, Ponette E 1982 Yersinia enteritis. Medical Clinics of North America 66: 639-653.

Vesikari T, Nurmi T, Maki M, Skurnik M, Sundqvist C, Granfors K, Gronroos P 1981 Plasmids in Yersinia enterocolitica serotypes $0: 3$ and $0: 9$ : Correlation with epithelial cell adherence in vitro. Infection and Immunity 33: 870-876.

Winblad S. 1973 Studies on the O-serotype of Yersinia enterocolitica. In: Winblad S (ed) Yersinia, pasteurella and francisella (Contributions to Microbiology and Immunology, 2) Karger, Basel. pp 27-37. 